\title{
EQUILIBRIUM IN INSURANCE MARKETS WITH FXPERIENCE RATING
}

Howard Kunreuther

Mark Pauly

November 1981

CP-81-32

Collaborative Papers report work which has not been performed solely at the International Institute for Applied Systems Analysis and which has received only limited review. Views or opinions expressed herein do not necessarily represent those of the Institute, its National Member Organizations, or other organizations supporting the work.

INTERNATIONAL INSTITUTE FOR APPLIED SYSTEMS ANALYSIS

2361 Laxenburg, Austria 



\section{ABSTRACT}

This paper investigates the properties of equilibrium in insurance markets where insurers can obtain specific and private knowledge of the loss experience of their customers. We examine the case where firms obtain information over time from insurance claims and use these data in a Bayesian fashion to adjust individual premiums to experience.

We first consider the case where firms can change their premiums from one period to the next and customers are free to stay or leave as they see fit. We refer to this case as a single period equilibrium. The resulting premium schedule earns monopoly profits even if entry by new firms into the insurance market is perfectly free. We next investigate a myopic multi-period equilibrium, in which firms maximize the present value of the stream of expected profits over the period in which the individual is insured, but individuals select the firm offering the lowest premiums. With free entry, expected profits are zero but premiums are generally too low or too high relative to actuarial values. We also investigate the properties of a full multi-period equilibrium where insurance firms specify premiums in advance for all future periods as a function of the number of claims that a customer has made within a given time span. In this type of equilibrium long-run profits are zero and insurance firms consciously charge actuarially unfair premiums to some of their customers.

Although these models are illustrated in an insurance context, they also apply to other situations as well, notably labor markets. The concluding sections briefly explores these extensions and draws out lessons for regulatory policy. 
1 
CONTENTS

I. INTRODUCTION 1

II. NATURE OF EQUILIBRIUM IN INSURANCE MARKETS

$\begin{array}{ll}\text { Stability of Equilibrium } & 10\end{array}$

An Illustrative Example $\quad 12$

Welfare Effects $\quad 15$

III. INFORMED FIRMS: LEARNING OVER TIME $\quad 15$

Nature of Equilibrium 15

An Illustrative Example 18

Obtaining Verified Information $\quad 21$

Extensions of the Model 23

Increasing the Number of Risk Classes $\quad 23$

Imperfect Information by Consumers $\quad 24$

IV. MULTI-PERIOD MODELS 24

A Myopic Multi-Period Model 25

$\begin{array}{ll}\text { Full Multi-Period Equilibrium } & 28\end{array}$

V. CONCLUSIONS

Behavioral and Regulatory Implications 31

other Applications and Extensions 32

$\begin{array}{lr}\text { REFERENCES } & 35\end{array}$ 


\title{
EQUIIJBRIUM IN INSURANCE MARKETS WITH FAXPERIENCE RATING
}

\author{
Howard Kunreuther and Mark Pauly
}

\section{INTRODUCTION}

Asymmetry of information between parties to a market transaction has been extensively disclissed by economists in recent years. This paper investigates the functioning of insurance markets in which insurers can obtain specific and private knowledge of the characteristics of their customers. In particular, we focus on the case where the insurer obtains "inside information" by observing the loss experience of its customers and utilizes these data to charge differential premiums. This type of "experience rating" of individuals or groups is commonly used by firms in setting rates for automobile, health, life and unemployment insurance.

\footnotetext{
The research reported in this paper is partially supported by the Bundesministerium fuer Forschung und Technologie, F.R.G., contract no. 321/7581/RGB 8001 . While support for this work is gratefully acknowledged, the views expressed are the authors' and not necessarily ahared by the sponsor. We are grateful to Zenan Fortuna and Serge Medow for computational assistance and to David Cummins and the participants in the Conference on Regulation of the International Institute of Management, Berlin. July, 1881, especially Jorg Finsinger and Paul Kleindorfer for helpful comments and suggestions. An earlier version of this paper is included in the conference proceedings.
} 
Our approach is motivated by recent literature on adverse selection in insurance and other markets. This problem was placed in the broad perspective of differential information by Akerlof's (1970) discussion of "lemons." Arrow (1963) previously showed in the context of health insurance and medical care, that there can be a market failure due to adverse selection if consumers have perfect information on their risk but the insurer is ignorant.

Two characteristics of the information the insurer collects from observing his policyholders' experiences are crucial:

(1) In general, the information will be incomplete at any point in time, in the sense that an individual's past experience with that insurance firm will not provide a completely accurate indicator of the person's risk probability.

(2) The insurer will not be willing to communicate this history to other insurers, and the individual will not be able to communicate it in a fully verifiable way. If the only agent who can verify an individual's history is his current insurance firm, this history will be private knowledge for that firm. Other firms may be able to obtain external verification of an individual's record but only at some cost. ${ }^{2}$

Although we illustrate our models in an insurance context, they also apply to other situations as well, notably labor markets. In particular, the results of our analysis may provide the basis for a model of internal labor markets which is in the spirit of the work by Williamson, Wachter, and Harris (1975). For example, employers may not be able to characterize their employees by productivity class when they join the firm initially but they are able to "experience rate" workers by observing their behavior on the job. This information will be private so that employees may have difficulty signaling their skills to other firms.

\footnotetext{
David Cummins has pointed out to us that automobile insurance firms are able to obtain information on driving records from state motor vehicle departments. These driving records, however, may be an imperfect substitute for claim records maintained by insurance companies, since accidents and traffic tickets are not perfectly correlated.
} 
While the general case of labor markets with imperfect information about productivity has been extensively investigated, ${ }^{3}$ there has not been, to our knowledge, an explicit consideration of the existence of or the properties of equilibrium when informational asymmetry can be induced by the passage of time. We will suggest that the character of equilibrium helps explain the persistence of long-term relationships between worker and employer, or between customer and firm for goods where quality is known only by experience.

The following problem is analyzed in detail. Suppose that a set of customers has been with a specific insurance firm for $t$ years during which time the firm has collected information on their claims experience. The insurer naturally does not make this data available to other firms. and consumers are unable to furnish verified histories. Not having direct knowledge of each customer's risk class, the insurance firm utilizes claims data to set premiums. What schedule of rates should be set so that no customer will have an incentive to purchase insurance elsewhere in period $t+1$ ?

We consider two polar cases with regard to the assumption made about firm behavior. At one extreme, we assume that the firm has no foresight, so that it must be able to set a price to make non-negative expected profits in every period. At the other extreme, we assume that the firm has perfect foresight, in the sense that it maximizes the present discounted value of the expected profit stream over a planning horizon, regardless of the level of profits in any one period. We also consider two polar assumptions about consumer foresight: either consumers choose the firm making the most attractive offer in the current period, or they have the foresight to consider the stream of premiums that will be charged in the current period and in all future periods based on their loss experience.

\footnotetext{
${ }^{3}$ See in particular the papers by Burdett and Mortensen (1980), Riley (1979), and Hashimoto and $Y u(1880)$.
} 
We refer to the situation in which neither firm nor customer has foresight as a single-period equilibrium since firms can change their price from one period to the next and customers are free to stay or leave as they see fit. We refer to the situation in which firms maximize discounted expected profits but consumers choose only on the basis of current period premiums as myopic multi-period equilibrium. Finally, we refer to the situation in which both consumers and firms have foresight as full multi- period equilibrium. ${ }^{4}$

The paper is organized as follows. We first begin at the end, so to speak, by considering in Section II a static model in which the firm currently selling insurance to an individual is fully informed about his risk class. Section III develops a model in which firms obtain such information over time from the claims experience of the insured and use this information in a Bayesian fashion to adjust individual premiums to experience. We show that in the single-period equilibrium model, the resulting premium schedule yields positive expective profits and monopoly distortions even if entry by new firms into the market is completely free. Profit or rate regulation would be a natural remedy if reality approximated this equilibrium. We further consider briefly the impact on the single period equilibrium of permitting customers to buy verified information on their experience. This would include purchase of data on premium classifications or claim records.

Section IV is devoted to multi-period models. We show that in the myopic multi-period equilibrium, expected profits are zero with free entry, but price distortions remain. Premiums are generally below expected costs in the early periods, but eventually rise to exceed expected costs. In full multi-period equilibrium firms will offer consumers multi-period policies which specify in advance the way premiums will vary with a customer's experience. Firms must then abide by this schedule, but customers can seek insurance elsewhere at any time. (This

\footnotetext{
4 One of the purposes of experience rating is to cope with problems of moral hazard. It does this by rewarding those who do not make claims on their policy in period $t$ with lower premiums in the next period. This paper does not answer the question analytically as to whether these type of premium adjustment processes eliminates or substantially reduces morel hazard.
} 
model is like explict contracting in labor market theory.) We show that, in equilibrium, expected profits will be zero but firms will consciously charge some customers actuarially unfair premiums. We conjecture that this equilibrium is Pareto optimal so that regulation, far from being helpful, may actually inhibit the attainment of optimality if it requires premiums to be equal or proportional to the actuarially fair premiums for individuals classified by loss frequency. The concluding section draws out lessons for regulation policy and suggests possible applications and extensions of the analysis.

\section{NATURE OF EQUILIBRIUM IN INSURANCE MARKETS}

The existence and character of equilibrium in insurance markets with adverse selection has been dealt with by Rothschild and Stiglitz (hereafter referred to as R-S) (1976) and Pauly (1974). R-S suggest that firms will market insurance contracts which specify price and the total amount of insurance purchased to potential customers. The total quantity of coverage acts as a signal to differentiate the high and low risks. Pauly, in contrast, suggests that insurers cannot be expected to obtain accurate information on the total purchases of any individual, since it will be in the interest of the individual and a supplemental insurer to conceal the fact of purchase. Extensions of the R-S approach, using different concepts of static equilibrium, have been provided by Wilson (1977), Miyasaki (1977), Jaynes (1978), Spence (1978), and Grossman (1979). Pauly's approach has been analyzed by Johnson (1978).

In this paper we make Pauly's assumption that firms do not know the total amount of insurance an individual has purchased. We do so for three reasons:

1. The empirical support for the assumption that all firms do exchange information about total purchases of insurance is weak. While some firms exchange such information, the frequency of complaints about the failure of such "coordination of 
benefits" schemes is legion (Follman 1963).

2. If insurers do not have accurate information on total purchases then there is an incentive for individuals to purchase policies from several firms and conceal their portfolio. This type of behavior prevents any firm from marketing a set of "pricequantity" policies since potential customers will always purchase the portfolio of policies with the lowest cost per dollar coverage.

3. Suppose one accepts the R-S assumptions that firms can monitor total purchases and that insurance demand varies with risk class. Then the quantity of insurance bought by any customer is a perfect and instantaneous signal of the individual's risk category. ${ }^{5}$ Consequently, adverse selection ceases to be a problem.

Dur world consists of two types of consumers. Every consumer faces a possibility of an identical single loss $(X)$ which is correctly estimated and which is independently distributed across individuals. Each consumer type $i$ has a different probability of a loss, $\Phi_{i}, i=H, L$ for the high and low risk group respectively $\left(\Phi_{H}>\Phi_{L}\right)$. The consumers correctly perceive these values of $\Phi_{i}$. The proportion of high and low risk consumers in the population is given by $N_{H}$ and $N_{L}$ respectively. Type i's preference is represented by a von Neumann-Morgenstein utility function, $U_{i}$, and each consumer determines the optimal amount of insurance to purchase by maximizing expected utility $E\left(U_{i}\right)$.

The insurance industry consists of $n$ firms, all of whom estimate $X$ correctly. We initially assume that each consumer has been insured by the same firm for a sufficiently long period of time that the insurer has collected enough information through claim payments and other data to

\footnotetext{
Indeed, the signal is so good that, if all individuals have the same utility function, the mere decision to purchase a particular quantity of insurance signals the individual's risk class; a person who has signaled that he is low risk by choosing the small quantity policy could then be offered full coverage at a rate near the actuarial level for good risks. Hence, even when an R-S equilibrium occurs, it may be dominated by such a strategy. Of course, this new strategy may itself be dominated as consumers leam to respond by offering false signals about their initial most preferred policy.
} 
specify $\Phi_{i}$ exactly for each individual. The remaining $n-1$ firms in the industry cannot determine whether individuals insured by others are high or low risk people; an insured's past history is not and cannot be common knowledge. Each insurer offers a premium, $P_{i}$, the same for all individuals in risk group $i$, without specifying the amount of coverage, $Q_{i}$, which has to be purchased, except that $0 \leq Q_{i} \leq X$. If firms have information on the risk class of their clients they can charge differential premiums to high and low risk individuals; other firms in the industry are forced to charge the same premium to both groups because they cannot distinguish high risks from low risks. However, each firm does know how many periods the individual has been in the market, including whether he is a new customer.

We now characterize the strategies available to insurers and consider the possibility of equilibrium. With regard to a particular client, it is useful to think of firms as either being "informed," i.e, having sold a policy to an individual in the previous period, or "uninformed," i.e., treating the client as a customer new to that firm? Consider first the situation of a representative uninformed firm. It knows that each consumer has the insurance demand curve:

$$
D_{i}=f\left(\Phi_{i}, P_{i}\right), \quad i=H, L
$$

which is derived from constrained utility maximization. Since the uninformed firm cannot distinguish between risks, it will have to set $P_{H}=P_{L}=P$. In a free-entry world with firms that maximize expected profit $E(\pi)$, the breakeven premium $P^{*}$ for such firms would be given by the lowest value of $P$ such that:

$$
E(\pi)=\left(P^{*}-\Phi_{L}\right) Q_{L}+\left(P^{*}-\Phi_{H}\right) Q_{H}=0
$$

where $Q_{L}$ is the total amount purchased by $L$ 's and $Q_{H}$ is the total amount purchased by $H^{\prime} s$ at the uniform premium $P^{*}$. Figure 1 
illustrates the case of an equilibrium when both groups purchase insurance. The low risk group subsidizes the high risk group and purchases partial coverage $Q_{L}<X$, while high risk individuals purchase full coverage, $Q_{H}=X$, at subsidized rates. ${ }^{6}$

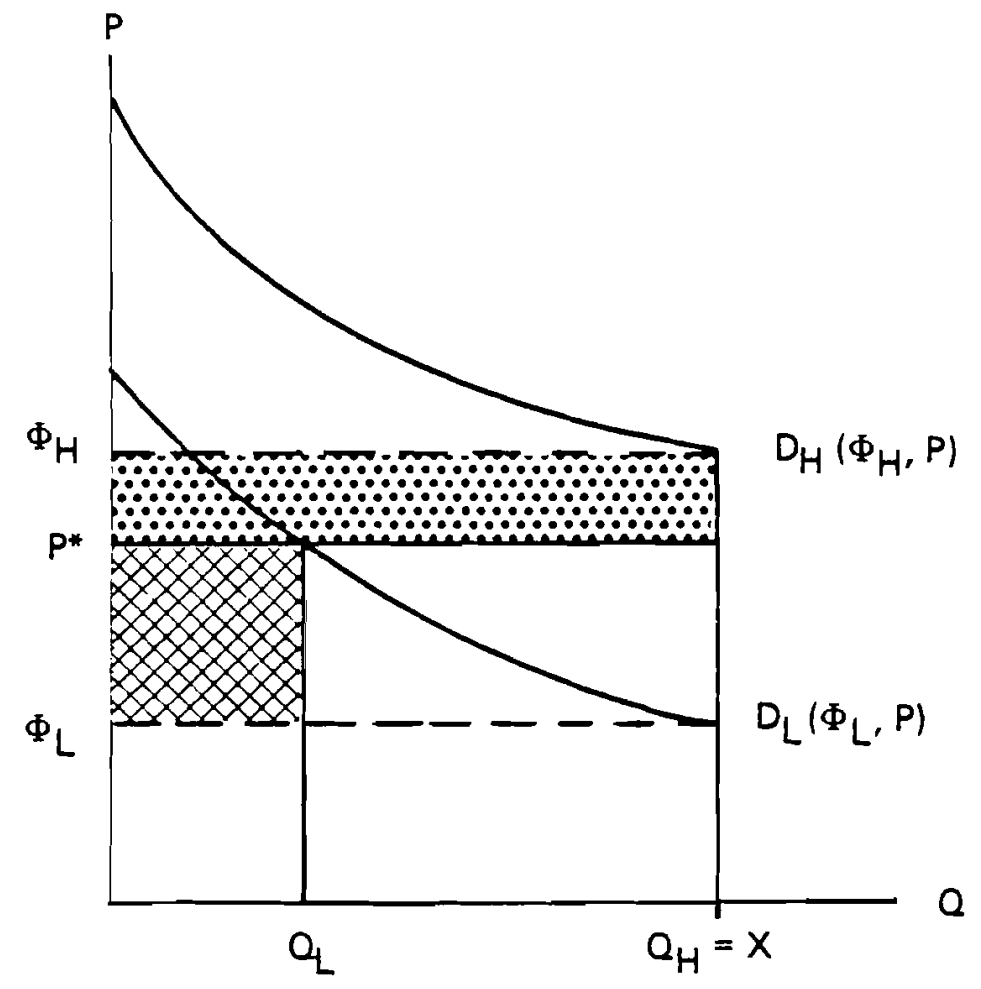

Figure 1:

The informed insurer can use his exact knowledge of each present customer's $\Phi_{i}, i=H, L$, to set rates tailored to each customer's experience. For high risk individuals, the informed firm will reduce its expected profits if it charges less than $\Phi_{H}$. For low risk individuals, the rate it will charge will depend on the premium charged by uninformed firms. The informed firm maximizes expected profits by charging low risk individuals a little less than the price offered by the uninformed firm

\footnotetext{
When the only value of $P$ which satisfies $(L)$ is $P^{*}=\Phi_{H}$, then $Q_{L}=0$. and the market will only provide coverage to high risk individuals. This is a case of market failure, since low risk individuals cannot purchase insurance due to imperfect information by firms.
} 
to all purchasers of insurance. (The uninformed firm's price must be larger than $P^{*}$ for it to earn profits.) The informed firm then attracts all low risks, and makes profits of $\left(P_{L}^{I}-Q_{L}\right) N_{L}$, which rises as $P_{L}^{I}$ rises. If uninformed firms are charging $P^{\bullet}+\delta$, for example, the informed firm will want to charge its low risk customers the lower of one of two rates. It will either charge $P^{*}$ or it will charge $\hat{P}_{L}$, the premium which would maximize profits on low-risk insureds if the firm were a monopolist. At the other extreme, if uninformed firms are charging $\Phi_{H}$ to everyone, then the informed firm will charge either $\Phi_{H}-\varepsilon$ or $\hat{P}_{L}$, whichever is less.

But just as the informed firm's optimal pricing strategy depends on the strategies selected by uninformed firms, so does an uninformed firm's strategy (and profits) depend on what the informed firm is doing. The strategic combinations and resulting outcomes are shown as the payoff matrix in Figure 2, with the upper expression in each cell (labeled 1-4) representing the payoff (profits) to the informed firm $(I)$, and the lower expression the payoff to the uninformed iirm $(U)$. When one type of firm obtains no business, and all customers purchase from the other type of firm, a profit level of zero is entered.

But just as the informed firm's optimal pricing strategy depends on the strategies selected by uninformed firms, so does an uninformed firm's strategy depend on what the informed firm is doing. The strategic combinations and payoffs are shown as the payoff matrix, in Figure 2 , with the upper expression in each labeled cell $1 \ldots 4$ being the payoff (profits) to the informed firm $(I)$, and the lower expression the payoffs to the uninformed firm $(U)$. When one type of firm obtains no business, and all customers purchase from the other type of firm, a profit level of zero is entered. Here we are assuming that both $P^{*}$ and $\Phi_{H}$ are less than $\hat{P}_{L} .{ }^{7}$

${ }$ If $\hat{P}_{L}$ is less than $P^{*}$, then the informed firm will always charge $P_{H}^{I}=\Phi_{H}$ and $P_{L}^{I}=\widehat{P}_{L}$ making positive profits. Uninformed firms will not obtain any business no matter what they do. 


\begin{tabular}{|c|c|c|}
\hline $\begin{array}{c}\text { Uninformed } \\
\text { Firm } \\
\text { Informed } \\
\text { Firm }\end{array}$ & $P^{U}=P^{*}+\delta<\Phi_{H}$ & $P^{U}=\Phi_{H}$ \\
\hline $\begin{array}{l}P_{L}^{I}=P^{*} \\
P_{H}^{I}=\Phi_{H}\end{array}$ & $\begin{array}{c}N_{L} Q_{L}\left(P^{*}-\Phi_{L}\right)>0 \\
N_{H} Q_{H}\left(P^{*}+\delta-\Phi_{H}\right)<0\end{array}$ & $\begin{array}{c}\frac{2}{N_{L} Q_{L}\left(P^{*}-\Phi_{L}\right)>0} \\
0\end{array}$ \\
\hline $\begin{array}{l}P_{L}^{I}=\Phi_{H}-\varepsilon \\
P_{H}^{l}=\Phi_{H}\end{array}$ & $\begin{array}{c}0 \\
\left(N_{L} Q_{L}+N_{H} Q_{H}\right)\left(P^{*}+\delta\right)-N_{L} Q_{L} \Phi_{L}- \\
N_{H} Q_{H} \Phi_{H}>0\end{array}$ & $\begin{array}{c}\frac{4}{N_{L}} Q_{L}\left(P_{H}-\varepsilon-\Phi_{L}\right)>0 \\
0\end{array}$ \\
\hline
\end{tabular}

Figure 2. Payoff Matrix for Informed and Uninformed Firms.

\section{Stability of Equilibrium}

We will now show that there is no stable Nash equilibrium where there are both informed and uninformed firms. The argument is simple. If $U$ (uninformed) firms chose $\Phi_{H}-\varepsilon$, then $I$ (informed) should choose $\Phi_{H}-\varepsilon$ to maximize profits. But if $I$ chooses $\Phi_{H}-\varepsilon$, there exists some $P^{*}+\delta<\Phi_{H}-\varepsilon$ at which $U$ can make positive profits, while $I$ gets no business and makes zero profit. But if $U$ plays $F^{*}+\delta$. I should charge a little less (e.g., $\left.P^{*}\right)$. Then $J$ makes positive profits, but $U$ suffers a loss. To prevent this loss, $U$ must charge at least $\Phi_{H}$. But then $I$ should charge $\Phi_{H}-\varepsilon$, etc. If there are many players, the absence of a Nash equilibrium makes stability unlikely. ${ }^{8}$

\footnotetext{
8 Note that, from the view point of a single uninformed firm, the maximum value that $\delta$ can take in cell 3 in Figure 2, depends on what the firm assurnes that the uninformed firms will do. If they continue playing strategy, $\Phi_{H}$, then the single uninformed firm can charge anything less than $\Phi_{H}-\varepsilon$ and capture all the business with a large profit. If each uninformed firm assumes the other uninformed firms will match its prices, then profits will be lower.
} 
What other concepts of equilibrium might apply here? If both parties followed maximin strategies, the outcome would be in cell 2 , with the strategy pairs $\left\{P_{L}^{I}=P^{*}, P_{H}^{l}=\Phi_{H}\right\}$ for the informed firm, and $\left\{P^{U}=\Phi_{H}\right\}$ for the uninformed firm. In this cell, the uninformed firm is sure that it will not lose money (although it will not make profits either). The informed firm guarantees itself positive profits. Thus, in a single-play context, or with a small number of players, we might expect the outcome to be in cell 2 .

Another possibility, already used in the literature on insurance markets and imperfect labor markets, is the concept of Wilson Equilibrium. ${ }^{9}$ A given set of actions is a Wilson equilibrium if no firm can alter its behavior (i.e., propose a different premium) that will (a) earn larger positive profits immediately, and (b) continue to be more profitable after other firms have dropped all policies rendered unprofitable by the initial firm's new behavior. Is the pair $\left\{P L=P^{*}, P_{H}^{l}=\Phi_{H}\right\}$ and $\left\{P^{U}=\Phi_{H}+\varepsilon\right\}$ a Wilson equilibrium? The alternative strategy for the informed firm is to set $\left\{P_{L}^{I}=P_{H}^{I}=\Phi_{H}\right\}$. This earns it larger profits and does not cause the uninformed firms to lose money if they maintain their same policy as before. However, an informed firm's charging $\left\{P L=P_{H}^{I}=\Phi_{H}\right\}$ would permit uninformed firms to make positive profits by switching to $P^{U}=P^{*}+\varepsilon$; this change reduces the informed firm's profit to zero. Thus, if we substitute the notion "rendered less profitable" for "rendered unprofitable" in part (b) of the above definition, then cell 2 does qualify as a Wilson equilibrium.

An alternative equilibrium concept which leads to the same conclusion is based on a Stackelberg leader-follower model. It seems reasonable to suppose that the (single) informed firm will play the leadership role. The reaction function for the uninformed firm is $P^{U}=f\left(P_{L}^{I}\right)$, and the informed firm therefore maximizes its expected profit $\left(\Pi^{I}\right)$ :

$$
\Pi^{I}=g\left(P_{L}^{I}, f\left(P_{L}^{I}\right)\right)
$$

9 It was proposed by Wilson (1877) and has been utilized by, among others, Miyasaki (1877), and Spence (1878), to characterize equilibrium. 
If the informed firm sets $P L=P^{*}$, then $P^{U}=f\left(P_{L}^{I}\right)=\Phi_{H}$, and $\Pi^{I}=N_{L} Q_{L}\left(P^{*}-\Phi_{L}\right)>0$. If the informed firm sets $P_{L}^{I}=\Phi_{H}-\varepsilon$, then $P^{U}=f\left(P_{L}^{I}\right)=P^{*}+\delta$, and $\Pi^{I}$ is zero. Hence, maximization of (3) requires $P_{L}^{I}$ to be $P^{*}$, and the Stackelberg equilibrium is given by cell 2 .

To summarize, there are two conclusions based on the above discussion: 10

(1) No single-period equilibrium exists, or

(2) A single-period equilibrium is represented by $\left\{P_{L}^{I}=P^{*}, P_{H}^{I}=\Phi_{H}\right\}$ for informed firms, $\left\{P^{U}=\Phi_{H}+\varepsilon\right\}$ for uninformed firms, with all business going to informed firms.

In what follows, we adopt the second conclusion by assuming that the informed and uninformed firms behave in a Stackelberg fashion, with the informed firm as the leader and the uninformed firms as the followers. This equilibrium is also achieved if one assumes that either firm follows a policy that maximizes the minimum profit they could attain no matter what uninformed firms did, or that the modified definition of a Wilson equilibrium is appropriate.

\section{An Illustrative Example}

A simple example, to be used further in the rest of the paper, illustrates how one determines a single period equilibrium for the above problem. ${ }^{11}$ Risk averse consumers of each type $i$ with wealth, $A_{i}$, want to choose a value of $Q_{i}$ given $\Phi_{i}$ and $P_{i}$ which maximizes $E\left[U_{i}\left(Q_{i}\right)\right]$. For this two state problem the formulation is:

$$
E\left[U_{i}\left(Q_{i}\right)\right]=\Phi_{i} U_{i}\left[A_{i}-X+\left(1-P_{i}\right) Q_{i}\right]+\left(1-\Phi_{i}\right) U_{i}\left(A_{i}-P_{i} Q_{i}\right)
$$

subject to

$$
0 \leq Q_{i} \leq X
$$

\footnotetext{
10 We have not considered the possibility of mixed strategies.

11 A more detailed discussion of this model appears in Kunreuther (1976).
} 
Let $R_{i}$ be the contingency price ratio

$$
R_{i}=\frac{P_{i}\left(1-\Phi_{i}\right)}{\left(1-P_{i}\right) \Phi_{i}}
$$

and define $R_{i}^{\max }$ and $R_{i}^{\min }$ as the values of $R_{i}$ where $Q_{i}=0$ and $Q_{i}=X$ respectively when one maximizes $E\left[U_{i}\left(Q_{i}\right)\right]$ without any constraint on $Q_{i}$. Then if

$$
U_{i}^{\prime}=\frac{d U_{i}}{d Q_{i}}>0 \text { and } U_{i}^{\prime \prime}=\frac{d^{2} U_{i}}{d Q_{i}^{2}}<0
$$

the optimal solution to (4) is given by:

$$
\begin{array}{rll}
Q_{i}=0 & \text { if } & R_{i} \geq R_{i}^{\max } \\
R_{i}=\frac{U_{i}^{\prime}\left(A_{i}-P_{i} Q_{i}\right)}{U_{i}^{\prime}\left(A_{i}-X+\left(1-P_{i}\right) Q_{i}\right)} & \text { if } & R_{i}^{\min }<R_{i}<R_{i}^{\max } \\
Q_{i}=X & \text { if } & R_{i} \leq R_{i}^{\min }
\end{array}
$$

Whenever $P_{i} \leq \Phi_{i}$, then $Q_{i}=X$, since in this range the premium is either actuarially fair or subsidized. Suppose both consumer types have identical utility functions given by the exponential $U_{H}(Y)=U_{L}(Y)=-e^{-c Y}$, where $c$ is the risk aversion coefficient. Then $Q_{i}$ is determined by

$$
\begin{array}{rll}
Q_{i}=0 & \text { if } & \left(\ln R_{i}\right) \geq c X \\
Q_{i}=X-\left(\ln R_{i}\right) / c & \text { if } & e^{c x}<R_{i}<1 \\
Q_{i}=X & \text { if } & R_{i} \geq 1
\end{array}
$$

Figure 3 depicts the profit maximizing set of premiums for the specific case where $\Phi_{H}=.30, \Phi_{L}=.10, X=40, c=.04$, and $N_{L}=N_{H}=.5$. Uninformed firms would be forced to charge both high and low risk customers $P^{*}=.254$. The informed firms maximize their expected profits by 


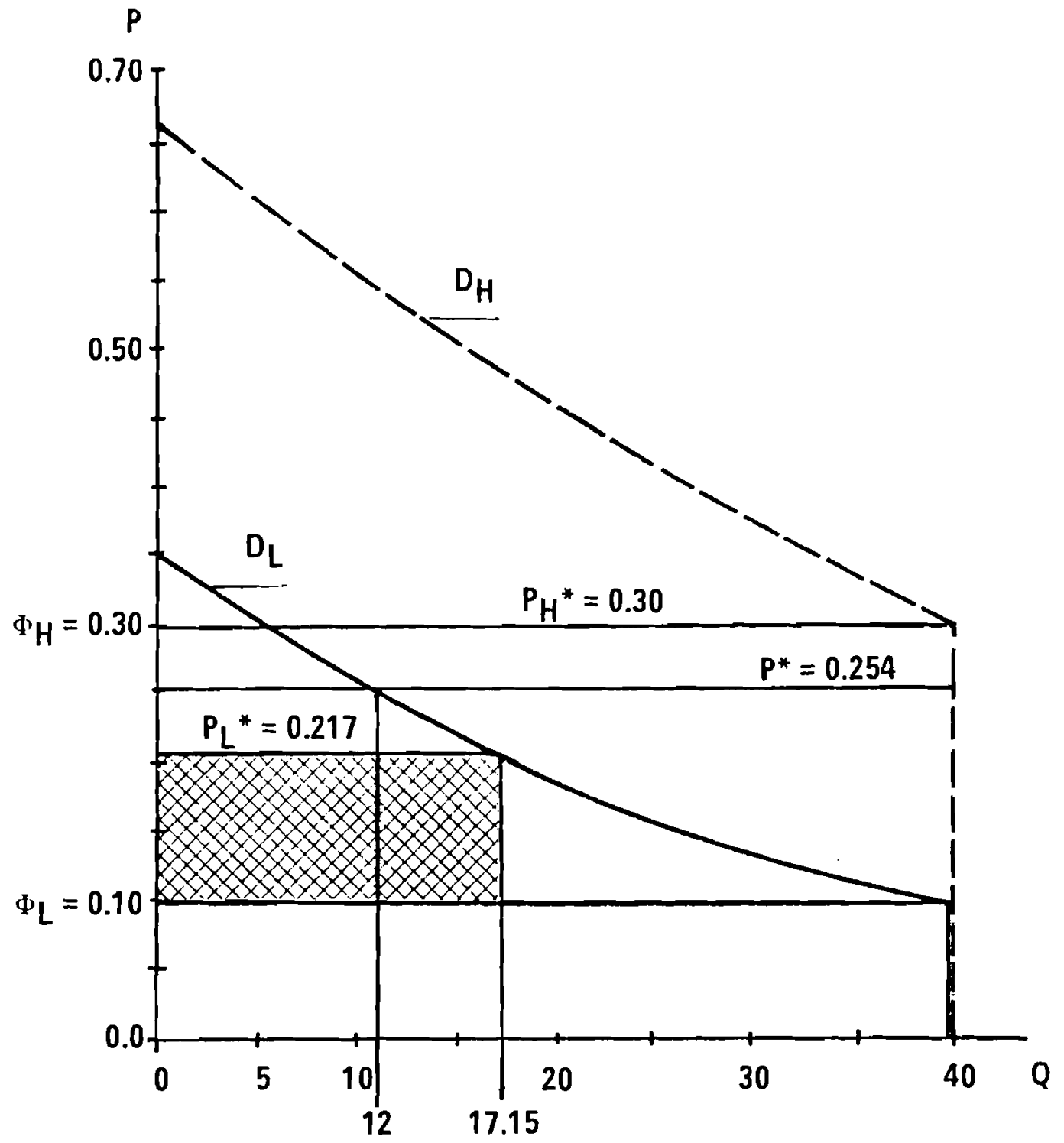

Figure 3. Optimal Premium Structure With Perfect Information on Risk Classes.

charging high risk customers $P_{H}^{*}=\Phi_{H}=.30$. The profit-maximizing premium charged to low risk customers is $P_{L}^{*}=217$. This yields expected profits for the low risk group of 2 , the cross-hatched area in Figure 3, i.e., $[(.217-.100)(17.15)]$. Aggregate expected profits are only 1 since only half of the individuals are in the low risk class. 


\section{Welfare Efffects}

In the no-information case, the equilibrium premium is $P^{*}$ for both high and low risks. When perfect information is available, and $P_{L}^{*}=P^{*}$, all of the gains from information go to informed insurance firms in the form of higher profits. If $P_{L}^{*}=\hat{P}_{L}$, the low risk individual benefits by the amount that the resulting premium is below $P^{*}$. The higher risk consumers are made unequivocally worse off with perfect information, since the price they pay increases from $P^{*}$ to $\Phi_{H}$. Moreover, the positive profits being earned by informed firms are not eroded by entry, since new firms are by definition uninformed ones.

\section{INFORMED FIRMS: LFEARNING OVER TIME}

\section{Nature of Equilibrium}

We now turn to the case where firms learn over time about the characteristics of their customers through loss data. Initially each firm only knows from statistical records that the proportion of high and low risk individuals in the insured population is given by $N_{H}$ and $N_{L}$ respectively where $N_{H}+N_{L}=1$. It does not know whether an individual is in the $H$ or $L$ class but does know how many periods each potential customer has been in the market (e.g., all 20 year old males are assumed to have been driving legally since age 16). Any new customer is offered a premium, $P^{*}$, which is defined as before so that

$$
E(\pi)=N_{L}\left(P^{*}-\Phi_{L}\right) Q_{L}+N_{H}\left(P^{*}-\Phi_{H}\right) Q_{H}=0
$$

We will assume that both $Q_{L}$ and $Q_{H}$ are greater than zero and that the insurer does not know how much insurance each person purchases. 
During each time period an individual can suffer at most one loss. which if it occurs will cause $X$ dollars damage. Any time a claims payment is made this information is recorded on the insurer's record and a new premium, which reflects his overall loss experience, is set for the next period. As before, we are assuming that informed firms do not disclose their records to other firms. Individuals who are dissatisfied with their new premium can seek insurance elsewhere. Other firms will not have access to the insured's record and hence cannot verify whether an applicant has had few or many losses under previous insurance contracts.

The informed firm uses a Bayesian updating process in readjusting its premium structure on the basis of its loss experience. Consider all customers who have been with the same insurance company for exactly $t$ periods. They can have anywhere from 0 to $t$ losses during this interval. The premium charged for period $t+1$ to individuals with $j$ losses during a $t$ period interval is $P_{j t, j}^{*}=0 \cdots t{ }^{12}$ Firms with loss experience data will set each premium $P_{j t}^{*}$ so that they maximize profits, subject to the constraint that customers remain with them. Let $w_{o o}^{L}$ and $w_{o 0}^{H}$ be the probabilities that an individual is in the low and high risk class when the firm initially insures him. We can update the probabilities by using Bayes procedure. If a customer has suffered exactly $j$ losses in a $t$ period interval then we define $w_{j t}^{i}, i=L, H$ as the probability that he is in the $i^{\text {th }}$ risk class, ${ }^{13}$ where $w_{j t}^{H}+w_{j t}^{L}=1$. The premium set for each loss classification will also be determined in part by the relative values of $w_{j t, i}^{i}=L, H$. As $j$ increases so does the probability that the individual is in the high risk class. Hence, $w_{j t}^{H}>w_{j-1, t}^{H}, j=1, \ldots, t$.

12 We are assuming that losses for an individual are independent of previous experience so the premium at the end of $t$ is determined only by the number of claims.

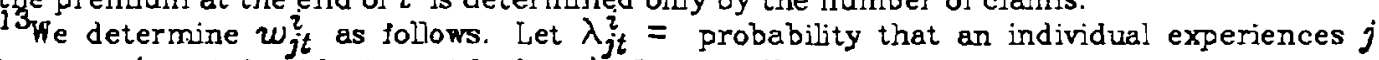
losses in $t$ periods, if he is in risk class $i$. Specifically,

Using Bayes formula

$$
\lambda_{j t}^{i}=\frac{t !}{(t-j) ! j !}\left(\Phi_{i}\right)^{j} \quad\left(1-\Phi_{i}\right)^{t-j}
$$

$$
w_{j t}^{i}=\frac{\lambda_{j t}^{i} N_{i}}{\sum_{i} \lambda_{j t}^{i} N_{i}}
$$


Suppose, for example, an informed firm offers a set of premiums $\left\{P_{j t}^{\prime}\right\}$ with $P_{j t}^{\prime}$ increasing as $j$ increases. ${ }^{14}$ An uninformed firm which charged a lower premium than $P_{j t}^{\prime}$ would attract all customers with $j$ or more losses. ${ }^{15}$ The proportion of high and low customers in their portfolio is given by

$$
W_{j t}^{i}=\frac{\sum_{k=j}^{t} w_{k t}^{i} s_{k t}}{\sum_{k=j}^{t} s_{k t}}
$$

where $s_{k t}=$ probability of a person suffering exactly $k$ losses in a $t$ period interval. In other words, $W_{j t}^{i}$ is a weighted average over the loss range $j \cdots t$. Since $w_{j t}^{H}$ increases with $j$ we know that $w_{j t}^{H}>w_{j t}^{H}$ for all $j=1 \cdots t-1$ and $w_{t t}^{H}=w_{t t}^{H}$.

The minimum premium $\left(P_{j t}^{\prime \prime}\right)$ at which expected profit equals zero for uninformed firms is given by:

$$
W_{j t}^{H}\left(P_{j t}^{\prime \prime}-\Phi_{H}\right) Q_{j t}^{H}+W_{j t}^{L}\left(P_{j t}^{\prime \prime}-\Phi_{L}\right) Q_{j t}^{L}=0
$$

where $Q_{j t}^{i}$ is demand for group $i$ given a premium $P_{j t}^{\prime \prime}$. We know that $P_{j t}^{\prime \prime}$ increases with $j$ since $W_{j t}^{H}$ increases with $j$. Hence any new firm which sets $P=P_{j t}^{\prime \prime}$ attracts only customers with $j$ or more losses and makes zero expected profits. So $(8)$ correctly describes the minimum level of premiums that uninformed firms can charge.

If the informed firm sets $P_{j t}=P_{j t}^{\prime \prime}-\varepsilon$ for only those customers who have suffered exactly $j$ losses, then these individuals will still prefer the informed firm. Its expected profits are given by

$$
E\left(\Pi_{j t}\right)=w_{j t}^{H}\left(P_{j t}-\Phi_{H}\right) Q_{H}+w_{j t}^{L}\left(P_{j t}-\Phi_{L}\right) Q_{L} \geq 0
$$

For sufficiently small $\varepsilon$, expected profits in $(9)$ are positive for 14 We will show below that $P_{j t}^{*}$ increases as $j$ increases.

15 Te are assuming no transaction costs for insured individuals to switch firms. 
$j=1 \cdots t-1$ since $w_{j t}^{H}$ is less than $w_{j t}^{H}$. For $j=t$, as $\varepsilon \rightarrow 0$. profits by definition will also approach zero since $w_{t t}^{i}=w_{t t}^{i}$

To determine the premium structure, an informed firm will also have to find the monopoly premiums $\left\{\widehat{P}_{j t}\right\}$ for each $j=0 \cdots t$, which maximize $E\left(\Pi_{j t}\right)$. It will maximize expected profits for each loss category if it then sets premiums $\left(P_{j t}^{*}\right)$ as follows

$$
P_{j t}^{*}=\min \left\{P_{j t}^{\prime \prime}-\varepsilon, \hat{P}_{j t}\right\}, j=0 \cdots t
$$

The structure of the premiums is thus identical to the case of perfect information outlined above except that profits will be lower because firms must now use claims information to categorize their customers and hence will misclassify some of them. Aggregate expected profits for each period $t$ are given by

$$
E\left(\Pi_{t}\right)=\sum_{j=0}^{t} s_{j t} E\left(\Pi_{j t}\right)
$$

\section{An Illustrative Example}

A two period example using the same parameters as in the previous problem illustrates the differences between learning from loss experience and having perfect information on insured individuals. Initially the firm sets the same premium as before--i.e., $P^{*}=.254$ from (7). Table 1 illustrates how one calculates the weights for determining the optimal premium structure at the end of period 1 when $j=0$ or 1 , and Figure 4 details the optimal rate structure at the end of period 1. The optimal premiums are $P_{01}^{*}=.254$ and $P_{11}^{*}=.288$ since $\hat{P}_{01}=\hat{P}_{11}=.495$. The premium charged to the group suffering one loss $\left(P_{11}^{*}\right)$, yields $E\left(\Pi_{11}\right)=0$ since $P_{11}^{*}=P_{11}^{\prime \prime}$, and $w_{11}^{H}=W_{11}^{H}$. Expected profits for the "zero loss" class is given by $(9)$ and is 
$-19-$

$E\left(\Pi_{01}\right)=.5625(.254-.10) 12+.4375(.254-.30) 40=.23$.

Aggregate expected profits for period 1 are given by (10) and in this case are $E\left(\Pi_{1}\right)=.8(.23)=.18$.

Table 1: Calculation of Weights $u_{j 1}^{i}$ and $w_{j 1}^{i} i=L, H$ for Two Period Yodel.

$$
\Phi_{L}=.1 \quad \Phi_{H}=.3 \quad X=40 \quad c=.04 \quad N_{H}=N_{L}=.5
$$

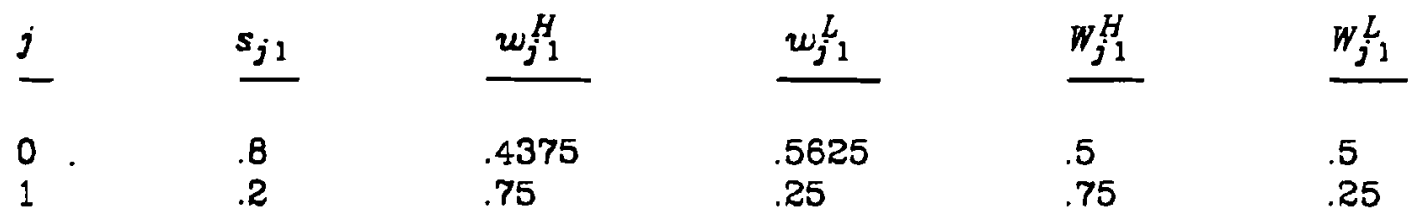

$$
s_{01}=\left(1-\Phi_{H}\right)\left(N_{H}\right)+\left(1-\Phi_{L}\right) N_{L}
$$

$s_{11}=\left(\Phi_{H}\right)\left(N_{H}\right)+\Phi_{L} N_{L}$

$$
i=L . H \quad\left\{\begin{array}{l}
w_{01}^{i}=\frac{\left(1-\Phi_{i}\right) N_{i}}{s_{01}} \\
w_{11}^{i}=\frac{\Phi_{i} N_{i}}{s_{11}} \\
w_{00}^{i}=\frac{\sum_{k=0}^{1} w_{k 1}^{i} s_{k 1}}{\sum_{k=0}^{1} s_{k 1}} \\
w_{11}^{i}=w_{11}^{i}
\end{array}\right.
$$




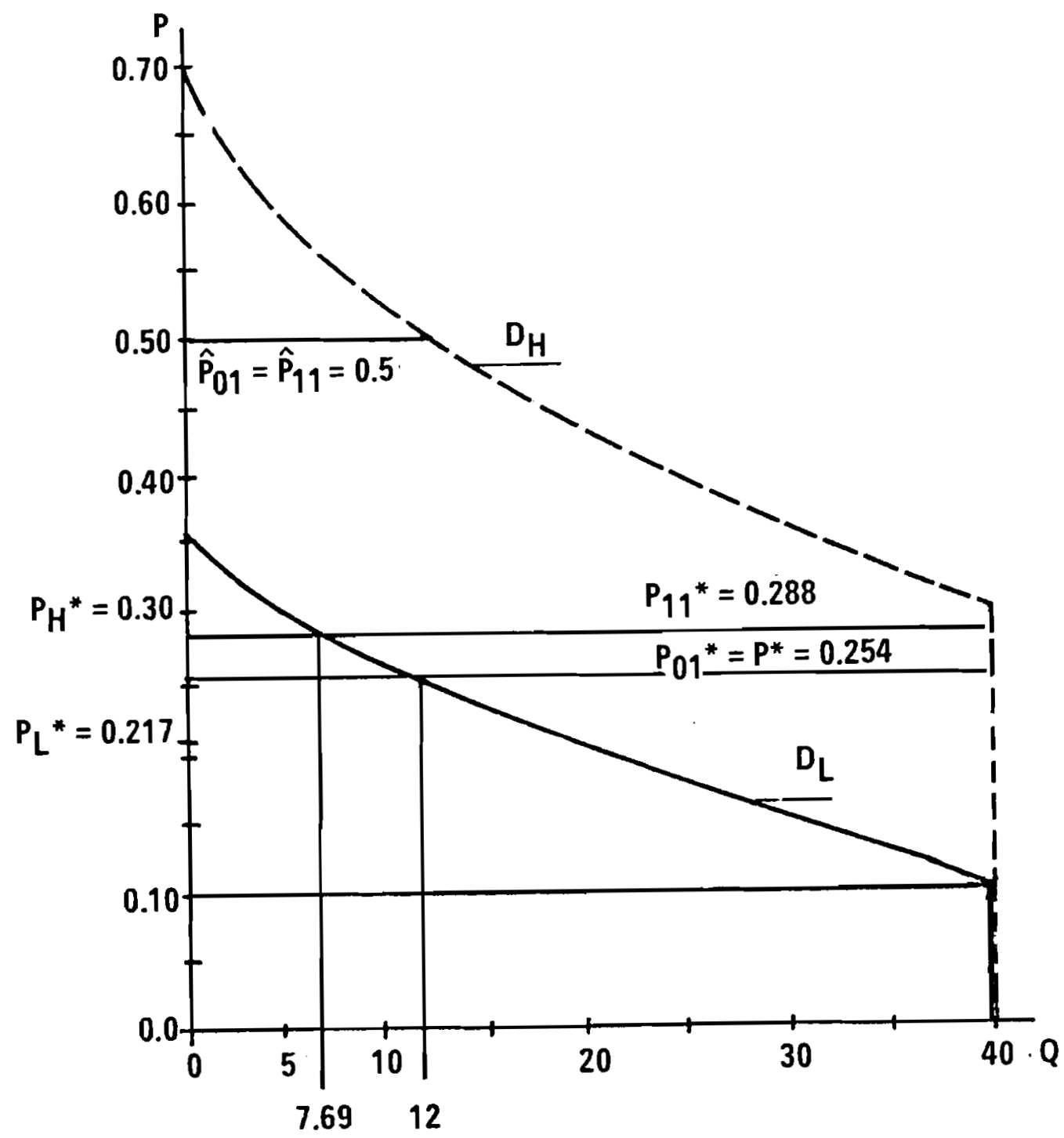

Figure 4. A Two Period Example Based on Loss Experience. 
It is worthwhile to focus on the welfare effects of experience rating when $t=1$. In the case of two groups, those with the highest risk will either pay an actuarially fair rate or be subsidized by the low risk group. The misclassification of individuals thus always benefits those in the $H$ class: either they are misclassified by being placed in the lower premium category (because they don't suffer a loss in period 1) or they suffer a loss but have a premium lower than $\Phi_{H}$ because some low risk individuals also have the bad luck to incur a loss in period 1. It also follows that the low risk individuals are charged premiums above $\Phi_{L}$, because of the firm's ability to exploit inside information. In the above example we see that the premium for low risk individuals would have been $P_{L}^{*}=.217$ if the tirm had perfect information on each individual; it was actually $P_{11}^{*}=.288$ or $P_{01}^{*}=.254$ depending on whether or not the individual experienced a loss in period 1. If the firm had wanted to break even on each rate class, it would have charged the same premium for customers with one loss but a premium of .237 for those with zero losses.

As a customer's life with the company increases then he faces a larger number of rate classes reflecting the possible outcomes. Firms makes the largest profit on those customers who experience the fewest losses. In the limit as $t \rightarrow \infty$, all customers will be accurately classified and we have the case of perfect information. Figure 5 graphically depicts how aggregate expected profit changes over time as a function of proportion of low risk customers in the population. As $N_{L}$ decreases then the informed firm's profit potential decreases since a larger proportion of individuals will suffer losses.

\section{Obtaining Verified Information}

The problem in achieving optimality arises, of course, because informed firms--the ones from which the consumer is currently purchasing--obtain positive profits in the long run. A natural response of low risk consumers facing such a situation is to seek some way of providing reliable information on their status to other insurance firms. There are two ways in which such data might be disseminated: (1) Consumers 


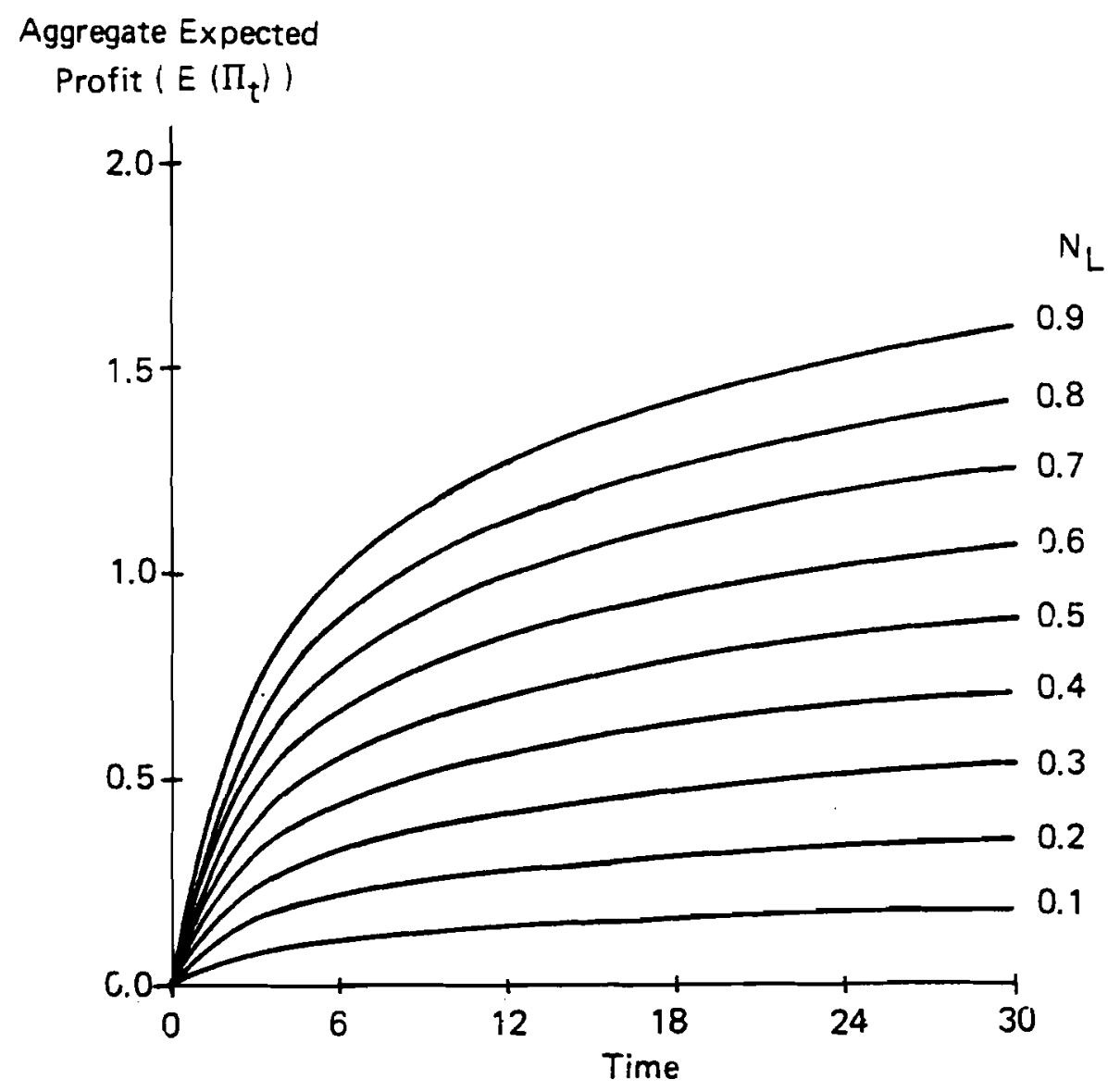

Figure 5. Aggregate Expected Profits $\left[E\left(\Pi_{t}\right)\right]$ as a Function of Proportion of Low Risk Customers $\left(N_{L}\right)$ and Time $(t)$.

might provide verified information on their actual number of losses (claims), and/or (Z) Consumers might provide verified information on the size of their premium bill for a given level of insurance, since this is a perfect indicator of the risk class into which they are being placed by their current insurer.

We would expect that consumers will find it difficult and costly to undertake either of these actions. For one thing, the current insurer has 
an incentive to conceal its claims and premium data. For another thing. purchasers of insurance who have had unfavorable loss experiences may try to represent themselves as being a better risk by using techniques such as bogus invoices, or applying for insurance right after an accident but before a new bill is issued. Note that the informed firm will not discourage such behavior, because it makes it more difficult for customers with good experience to communicate their status reliably.

The cost of communicating reliable information, will still permit the original insurer to earn some positive profits and the single period model is still relevant as a polar case. One could incorporate the costs of communicating of verified information into a more general model of the choice processes of insurers and insured. Profits would then be limited by the alternatives available to consumers re the purchasing verified information.

\section{Extensions of the Model}

The model of firm behavior was based on a number of simplifying short-term equilibrium assumptions which can now be relaxed without changing the basic qualitative results regarding equilibrium: viz, entry will be restricted in an industry where firms have inside information and monopoly profits will result if there is no regulation.

\section{Increasing the Number of Risk Classes}

As the number of risk classes increases the computations become more complicated but the nature of the solution remains the same as in the above case. The highest risk class will either pay the actuarial rate or be subsidized by the lower risk classes. Firms will make profits by exploiting their inside knowledge that some individuals are good risks. Firms without these data cannot determine whether an applicant has had few or many losses; hence, they have to assume he is an average individual. 
Imperfect Information by Consumers

If consumers do not have accurate estimates of the risks they are facing, then firms can exploit this imperfection if they have statistical data on which to base their estimates. Even if they cannot identify the risk category of each individual they can charge a set of premiums which maximizes their expected profits and still maintains their customers. We thus have a mixture of a purely competitive market and monopoly in determining the final rates. As Kleindorfer and Kunreuther (1981) and others, have shown, a stable competitive market will lead to a premium based on the true risk even if consumers misperceive it. Otherwise a firm can enter and make positive profits by charging a premium slightly above the actuarial rate. In our model, imperfect information will have no impact on the rate setting process for any values of $P_{j t}^{*}=P_{j t}^{\prime \prime}$. Whenever the firms finds that $P_{j t}^{*}=\hat{P}_{j t}<P_{j t}^{\prime \prime}$ it will then take advantage of inaccuracies by the consumer by setting a rate based on consumer misperceptions of the risk.

\section{MULTI-PETIOD YODELS}

We now investigate the consequences of changing the assumption that there is no foresight. We first consider a model in which firms look beyond current period losses to potential future profits. Firms are therefore assumed to be concerned with the present discounted value of the profit stream they expect to earn. But purchasers are still assumed to be myopic, in the sense that they choose which insurer to patronize by looking only at current period premiums. A second model permits both consumers and firms to have foresight. Consumers choose (in the initial period) that firm which offers them the highest lifetime utility. Consumers are free to leave firms if they wish, but firms are required to abide by the agreed-upon schedule of premiums as a function of the consumer's loss experience. 


\section{A Myopic Multi-Period Model}

Suppose that the firm is willing to tolerate losses for a while in order to attract customers and observe their loss experiences. It can then use this information to make profits in the future to offset (in present value terms) the initial losses. Consumers are still assumed to behave in a myopic fashion, in the sense that they choose in each period whichever insurer quotes the lowest premium for that period.

It is easy to see that the "single-period" premium schedule $\left\{P_{j t}\right\}$ may not be an equilibrium. On the one hand, a firm that charged less than $P_{00}^{*}$ in the initial period would have an expected loss in that period, on the other hand, it would have the opportunity to observe which individuals did and did not have losses during that period. If it used that information to change the schedule $P_{j t}^{*}$ in subsequent periods, the present discounted value of the profit stream associated with this pricing policy could be sufficient to offset the initial expected losses. Hence, a new schedule, with the lower $P_{o 0}$, would dominate the single-period equilibrium schedule.

What new set of premiums would represent an equilibrium schedule? An equilibrium schedule would be one where, for all $t$ and $j$, there would be no opportunity for a previously uninformed firm to enter and earn positive expected profits. To simplify the explanation of how this schedule is derived, we assume an interest rate of zero, so as not to be concerned with discounting. We assume that the firm which has attracted a customer in period 0 , will want to set its premiums for all future periods up to the end of the planning horizon $T$ so that no firm entering the market in later periods can attract any set of its customers and make a stream of profits whose sum is positive. That is, it will want to set $P_{j t}^{* \bullet}$ so that

$$
E\left(\pi_{j t}^{* *}\right)=\sum_{k=t}^{T}\left[w_{j k}^{L}\left(P_{j k}^{* *}-\Phi_{L}\right) Q_{j k}^{L}+w_{j k}^{H}\left(P_{j k}^{* *}-\Phi_{H}\right) Q_{j k}^{H}\right]=0
$$

for all $j$. Here $P^{\infty}$ is also the price that the new entrant would charge. 
The procedure in constructing a set of premiums $P^{\bullet \bullet}$ requires one to start at period $T$ and work backwards. Any uninformed firm who enters the market at the beginning of period $T$ must break even, because there is by definition no future period in which losses can be recouped. Hence, $P_{j T}^{* \ddot{ }}=P_{j T}^{*}$ for all $j$. Now consider period $T-1$. If a firm entered in this period it could observe the experience of its customers for one period and make profits on on all those individuals who did not have a loss during this period

The expected profits in period $T$ are derived using the same type of Bayesian updating procedure described in Section III. In order to prevent new entrants from coming into the market in period $T-1$, the informed firm must set its premium in period $T-1$ sufficiently low so that a potential new entrant would suffer a loss just a little larger than the profit he would earn in period $T$. As in the single period equilibrium model, there will be a different premium for each value of $j$. This set of policies $\left\{P_{j, T-1}^{* *}\right\}$ would then be the equilibrium schedule for the fully informed firm.

The same type of reasoning is utilized to compute the equilibrium set of premiums for period $T-2$. In this case a potential entrant who attracts customers can make profits in periods $T-1$ and $T$ by utilizing claims information on their insured population. The informed firm will then have to set $\left\{P_{j, T-2}^{* 0}\right\}$ at levels which erase all these potential profits of a new firm. The same process is repeated sequentially for all periods through $t=0$.

To illustrate differences between resulting premiums in the single period and myopic multi-period equilibrium cases we consider the same example as in Section III with $T=5$. Table 2 compares the set of premiums and expected profits for the two models. In the single period equilibrium the informed firm's premium $\left(P_{o 0}^{*}\right)$ starts off equal to the average actuarial value $\left(P^{*}=.254\right)$ and increases above this level for customers who experience losses. In the myopic case, the initial premium, $P_{00}^{* 0}$, is less than $P^{*}$, and increases over time whether or not the person suffers a loss. ${ }^{16}$ As $t$ approaches $T$, the premiums for the two types of equilibria 16 It is theoretically possible for consumers initially to be charged a negative premium to attract them to the insurance company so that they could be charged higher premiums as $t$ increases. In this case, individuals could be given a free gift for taking out insurance, in an 
Table 2. Comparison Between Premiums and Expected Profits for Single Period Equilibrium and Myopic Multi Period Equiibrium Schedule for Five Period Problem.

Single Period Equilibrium

\begin{tabular}{|c|c|c|c|c|c|c|c|}
\hline $\begin{array}{l}\text { Period } \\
t \\
\text { Number } \\
\text { of } \\
\text { losses j }\end{array}$ & - & 0 & 1 & 2 & 3 & 4 & 5 \\
\hline 0 & $\begin{array}{l}P_{O_{t}} \\
E\left(\pi_{0,}^{*}\right)\end{array}$ & $\begin{array}{l}.254 \\
0\end{array}$ & $\begin{array}{l}.254 \\
.18\end{array}$ & $\begin{array}{l}.254 \\
.30\end{array}$ & $\begin{array}{l}.254 \\
.36\end{array}$ & $\begin{array}{l}.254 \\
.39\end{array}$ & $\begin{array}{l}.254 \\
.39\end{array}$ \\
\hline 1 & $\begin{array}{l}P_{1 t}^{*} \\
E(\pi, t)\end{array}$ & & $\begin{array}{l}.288 \\
0\end{array}$ & $\begin{array}{l}.286 \\
.02\end{array}$ & $\begin{array}{l}.285 \\
.04\end{array}$ & $\begin{array}{l}.283 \\
.08\end{array}$ & $\begin{array}{l}.281 \\
.12\end{array}$ \\
\hline 2 & $\begin{array}{l}P_{2 \ell}^{*} \\
E\left(\pi_{2 t}^{*}\right)\end{array}$ & & & $\begin{array}{l}.296 \\
0\end{array}$ & $\begin{array}{l}.296 \\
.00\end{array}$ & $\begin{array}{l}.295 \\
.01\end{array}$ & $\begin{array}{l}.294 \\
.01\end{array}$ \\
\hline 3 & $\begin{array}{l}P_{3 t}^{*} \\
E\left(\pi_{3 t}^{*}\right) \\
\end{array}$ & & & & $\begin{array}{l}.299 \\
0\end{array}$ & $\begin{array}{l}.299 \\
.00\end{array}$ & $\begin{array}{l}.298 \\
.00\end{array}$ \\
\hline 4 & $\begin{array}{l}P_{4 t}^{*} \\
E\left(\pi_{4 t}^{*}\right)\end{array}$ & & & & & $\begin{array}{l}.30 \\
.00\end{array}$ & $\begin{array}{l}.30 \\
.00\end{array}$ \\
\hline 5 & $\begin{array}{l}P_{5 t}^{*} \\
E\left(\pi_{5 t}^{*}\right)\end{array}$ & & & & & & $\begin{array}{l}.30 \\
0 \\
\end{array}$ \\
\hline$E\left(\pi_{i}^{*}\right)$ & & 0 & .18 & .32 & .40 & .48 & .52 \\
\hline
\end{tabular}

Myopic Multi Period Equilibrium

\begin{tabular}{|c|c|c|c|c|c|c|c|}
\hline $\begin{array}{l}\text { Period } \\
\text { Number } \\
\text { of } \\
\text { losses } j\end{array}$ & & 0 & 1 & 2 & 3 & 4 & 5 \\
\hline 0 & $\begin{array}{l}P_{0 t}^{*} \\
E\left(\pi_{0, t}^{*}\right)\end{array}$ & $\begin{array}{r}.191 \\
-121 \\
\end{array}$ & $\begin{array}{r}.225 \\
-.15 \\
\end{array}$ & $\begin{array}{l}.245 \\
.24 \\
\end{array}$ & $\begin{array}{l}.252 \\
.35 \\
\end{array}$ & $\begin{array}{l}.254 \\
.38 \\
\end{array}$ & $\begin{array}{l}.254 \\
.39 \\
\end{array}$ \\
\hline 1 & $\begin{array}{l}P_{1:}^{*} \\
E\left(\pi_{1 t}^{* *}\right)\end{array}$ & & $\begin{array}{r}.250 \\
-.21 \\
\end{array}$ & $\begin{array}{r}.280 \\
-.03 \\
\end{array}$ & $\begin{array}{l}.284 \\
.04 \\
\end{array}$ & $\begin{array}{l}.283 \\
.08 \\
\end{array}$ & $\begin{array}{l}.281 \\
.12 \\
\end{array}$ \\
\hline 2 & $\begin{array}{l}P_{2 t}^{* *} \\
E\left(\pi_{2 t}^{* *}\right)\end{array}$ & & & $\begin{array}{r}.286 \\
-.02 \\
\end{array}$ & $\begin{array}{r}.295 \\
-.00\end{array}$ & $\begin{array}{l}.295 \\
.01\end{array}$ & $\begin{array}{l}.294 \\
.01\end{array}$ \\
\hline 3 & $\begin{array}{l}P_{3 t}^{* *} \\
E\left(\pi_{3 t}^{* *}\right)\end{array}$ & & & & $\begin{array}{l}.299 \\
.00 \\
\end{array}$ & $\begin{array}{l}.299 \\
.00\end{array}$ & $\begin{array}{l}.298 \\
.00 \\
\end{array}$ \\
\hline 4 & $\begin{array}{l}P_{4 t}^{* *} \\
E\left(\pi_{4 t}^{* *}\right)\end{array}$ & & & & & $\begin{array}{l}.30 \\
.00 \\
\end{array}$ & $\begin{array}{l}.30 \\
.00 \\
\end{array}$ \\
\hline 5 & $\begin{array}{l}P_{5 t}^{*} \\
E\left(\pi_{5 t}^{* *}\right)\end{array}$ & & & & & & $\begin{array}{l}.30 \\
0 \\
\end{array}$ \\
\hline
\end{tabular}


converge as expected. In the single-period case, the stream of profits is positive, in all periods; in the multi-period myopic case the firm suffers losses in the early periods recouping them in later periods so that the expected stream of profits is zero

Table 2 reveals that there is a perversity and allocative inefficiency in the multi-period myopic case. Consumers are undercharged in the early periods but will find that their premiums are raised even if they are accident free. Persons nearing the end of their risk horizons (e.g., the aged who will only be driving for a few more years) will tend to be overcharged for insurance, whereas the young will tend to be undercharged. ${ }^{17}$ Hence, consumers will tend to over-purchase insurance in the early periods, and under-purchase insurance in the later periods. If regulation could be used to bring premiums closer to the actuarial values, there would be a welfare gain.

\section{Full Multi-Period Equilibrium}

We now consider whether consumers who wish to maximize their utility over the planning horizon would prefer a firm which offers a schedule other than $\left\{P^{*}\right\}$ or $\left\{P^{* *}\right\}$. We have already shown that the schedule $\left\{P^{*}\right\}$ would be dominated by $\left\{P^{* *}\right\}$. Suppose a firm could offer a conditional premium schedule $\left\{P_{j t}^{C}\right\}$, one which specified premiums in any future period as a function of the number of losses up to that point.

The schedule $\left\{P_{j t}^{C}\right\}$ will still ordinarily dominate $\left\{P_{j t}^{* \bullet}\right\}$ because, as we have seen, $\left\{P_{j t}^{* *}\right\}$ sets premiums whose deviation from actuarial value varies with $t$. Consumers would prefer a schedule which did not induce them to overpurchase in early periods, or underpurchase in later periods.

\footnotetext{
anglogous fashion to the approach used by savings banks to attract new accounts. 17 This is exactly the opposite direction of discrimination from that recently alleged in auto mobile insurance rate hearings in Massachusetts and New Jersey.
} 
A set of premiums is a full multi-period (or conditional) equilibrium schedule if it is preferred in period 0 by every low risk individual to any other policy that would generate zero or positive expected profits. Since all such premiums in $\left\{P_{j t}^{c}\right\}$ are less than $\Phi_{H}$, a policy which attracts low risks will also usually be preferred by high risks. The only other option for high risks is a policy with premiums $\Phi_{H}$ for each period, which will be chosen only if high risks are very averse to fluctuations in premiums or high and low risks have nearly identical risks. We assume here that high risks also purchase the equilibrium policy. ${ }^{18}$

Firms will therefore want to set a schedule of premiums $\left\{P_{j t}^{c}\right\}$ that maximizes the expected utility of low risk individuals $E\left(U_{L}\right)$, where the only basis for discriminating between risk classes is through loss experience. For any period $t+1$ the expected utility for a low risk person of a premium schedule $\left\{P_{j t}\right\} j=0 \cdots t$ is given by

$$
\sum_{j=0}^{t} \lambda_{j t}^{i}\left[\Phi_{L} U\left(A_{L t}-X+\left(1-P_{j t}\right) Q_{j t}^{L}\right)+\left(1-\Phi_{L}\right) U\left(A_{L t}-P_{j t} Q_{j t}^{L}\right)\right]=M_{t}
$$

where $A_{L t}=$ wealth level for low risk person at the end of period $t$ and $\lambda_{j t}^{i}=$ probability of $j$ losses in a $t$ period interval (see Footnote 13). By making the simplifying assumption that consumers and firms have the same discount factor, $\alpha$, then the optimal schedule for a low risk person is one which maximizes

$$
E\left(U_{L}\right)=\sum_{t=0}^{\infty} M_{t} \cdot \frac{1}{(1+\alpha)^{t}}
$$

subject to $E\left(\Pi_{t}\right)=0$ for all $t$. We have imposed a breakeven requirement in each period, because there is no utility gain to firms or consumers of 18 If high risk customers are not interested in this policy then some firms will offer two premium schedules, one to attract low risk consumers and the other for high risk customers. This situation is uninteresting for our analysis, since experience rating is not needed to discriminate between risk groups. 
shifting premiums from period to period. ${ }^{19}$ Note, however, that under this policy the insurer will not expect to break even on every risk class. People with many losses will be subsidized ex post by those with few losses. Yet a regulatory policy that required premiums to be proportional to actuarially fair ones for all risk classes would not, in fact, be as desirable to consumers.

The expression for $E\left(U_{L}\right)$ is the present discounted value of the stream of expected utilities. Given risk aversion, it is easy to see that maximization of $E\left(U_{L}\right)$ will require $P_{t t}$ to be less than $\lambda_{t t}^{L}$, while $P_{\text {ot }}$ will be greater than $\lambda_{\text {ot }}^{L}$, etc. That is, in order to reduce the risk associated with fluctuations in premiums as a function of losses, income is transferred from experience classes (states) in which few losses have occurred to experience classes (states) in which many losses have occurred.

In this model there are no informed or uninformed firms because all transactions take place in the same period. Hence, there will always be an equilibrium schedule since the game theoretic considerations of the single period model do not apply here. Given the assumptions of this model, we conjecture that the equilibrium schedule is also a Pareto optimum. For it is clear that if there was some way of making low and high risk persons all better off than under the equilibrium schedule, that schedule would then become an equilibrium. Of course, if firms could observe total purchases of insurance, there would be some conditional price-quantity policy that would be Pareto superior to the conditional price policy.

\footnotetext{
19 Of course, if firms had a lower $\alpha$ then consumers (say, because of better access to capita] markets), then consumers would prefer to shift premiums to later periods, in effect taking a loan (at better-than-usual interest rates) from the insurer.
} 


\section{CONCLUSIONS}

This paper has described three alternative concepts of equilibrium in insurance markets with experience rating. The single period policy enables firms to earn monopoly profits in the long-run. As a result, low risk customers are only marginally better off with experience rating than without it; high risk customers are worse off. With respect to the multiperiod equilibrium, expected profits of firms are zero and low risk individuals obtain a substantial increase in utility. The increase is smaller under the myopic multi-period policy than under the multi-period policy. In the latter case the insured population prefers premiums that have more of a leveling effect than would be implied by setting rates based solely on the number of losses.

\section{Behavioral and Regulatory Implications}

Which of these radically different insurance contracts are a better description of reality? The empirical evidence on consumer decision processes regarding insurance purchase behavior suggests that for some types of insurance many individuals have limited knowledge of premiums or available coverage (Kunreuther et al. 1978). Hence we hypothesize that one would often expect that few consumers attempt to obtain information on how their premiums will be adjusted with experience. They undoubtedly have a vague notion that such adjustments occur, but have no written information on their insurance policy as to what these changes are. Furthermore, an insurer cannot distinguish between new purchasers and bad risks seeking a better deal. Hence, the single period equilibrium model often appears to better describe real world behavior because both the consumer and firm have imperfect information.

If the single period equilibrium is the most likely one, then there are potential welfare gains from regulation to control monopoly profits and set more equitable rates. This can take the form of a ceiling on specific rates or a requirement that firms provide their customers with certified records of their previous accident records so all insurers have access to 
this information when deciding premiums for their new customers. Ideal rate regulation should require premiums to be set close to the actuarial experience for each class of risks rather than mandating uniform (nonexperienced) or community rating. This can be achieved either by having insurance commissioners require data on actuarial experience or simply by having them regulate the rate of return. With respect to certification of customer records, it is interesting to note that if firms were forced to disclose personal information on their customers, all insured individuals would be better off since monopoly profits will have been eroded away. 20

If, however, the true state of affairs is characterized by the multiperiod equilibrium conditions, then it would not be desirable to require premiums to be actuarially fair since this rate structure would be viewed as undesirable by consumers. On the contrary, optimality in that model requires premiums that are more "level" than actuarially fair ones, if people are risk averse. In short, ideal regulation requires determining the nature of equilibrium.

\section{Other Applications and Extensions}

The rationale for the coexistence of recurrent spot markets and internal labor markets directly follows from the above analysis. In recurrent spot markets we would expect all firms to have similar knowledge about the potential productivity of their employees. On the other hand, internal labor markets are appropriate for describing situations where the firm learns about different skills from experience. Low skilled workers are equivalent to the high risk group and do not change jobs because they are paid wages in excess of their marginal productivity. Highly skilled workers are equivalent to the low risk group because other firms cannot measure their special talents. They are thus paid a wage less than their marginal productivity but more than they could obtain

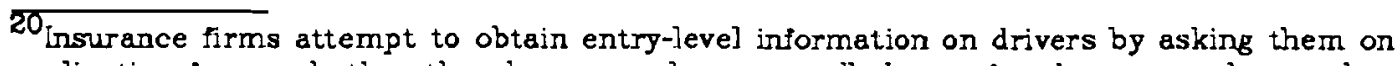
application forms whether they have ever been cancelled or refused coverage by another company. It is not clear, however, whether companies can check the accuracy of these responses. 
elsewhere.

We would expect that a long-run tenure contract or multi-period policy would be more appropriate in characterizing the labor market scene than insurance markets. High skilled workers have an incentive to bargain with firms to pre-specify wage payments as a function of productivity over time in order to reduce monopoly profits which emerge from period by period adjustments. The question of whether the resulting wage structure is a multi-period equilibrium is clouded by questions of monopoly powers of unions and monopsony power of certain firms.

The concept of experience rating over time suggests reasons for job classification schemes in much the same way that insurance systems have rate classification schemes. In this sense the models developed in this paper complement the important work of Spence (1973) on market signaling which provides a way of classifying individuals on the basis of observable traits such as educational status. There still may be difficulties in distinguishing between "good" and "bad" risks but these information imperfections will be reduced to the extent that a particular variable is an accurate discriminator.

Another relevant question relates to the implications for market behavior if firms use, or are forced to use, updating rules which differ from the Bayesian ones described above. For example, suppose firms have only 3 or 4 rate classifications no matter what happens to an individual and no matter how many periods he has been insured with a firm. In several European countries an individual who has had no losses for a certain number of consecutive years is automatically placed in the lowest rate classification. Most US companies do not consider a policyholder's record indefinitely but only process data for a limited number of periods such as five years. How would such procedures affect the equilibria for the high and low risk groups?

A final, and in me ay ways fundamental matter, is the development of a model of insurance premium setting. An individual or group's past experience is not the only information available to the insurance firm: premiums in practice depend both on experience and on certain individual characteristics, such as age, sex, marital status, etc. How should all 
of this information be used in determining a particular individual's premium, either from the viewpoint of Pareto optimality or from the viewpoint of competitive survival? How might imperfectly informed consumers interact with imperfectly informed firms? These questions are beyond the scope of this paper but suggest fruitful areas for increasing our understanding of insurance markets. 


\section{REFFRENCES}

Akerlof, G. 1970. "The market for lemons': Quality uncertainty and the market mechanisms." Quarterly Journal of Economics, B4:4B8-500.

Arrow, K. 1963. "Uncertainty and the welfare economics of medical care." American Economic Review, 53:941-973.

Burdett, K, and D. Mortensen. 1980. "Search, Layoffs, and Labor Market Equilibrium," Journal of Political Economy, 88:652-72.

Follman, Joseph Jr. 1963. Medical Care and Health Insurance. Homewood, Ill.: Irwin, Chapter 18.

Grossman, H. 1979. "Adverse Selection, Dissembling and Competitive Equilibrium," Bell Journal of Economics, 10:336-343.

Hashimoto, M., and Yu, B. 1980. "Specific Capital, Employment Contracts and Wage Rigidity." (mimeo).

Jaynes, G. 1978. "Equilibria in Monopolistically Competitive Insurance Markets," Journal of Economic Theory, 19:394-422.

Johnson, W. 1978. "Overinsurance and Public Provision of Insurance: Comment," Quarterly Joumal of Economics, 92:693-96.

Kleindorfer, P.R., and H. Kunreuther. 1981. "Consumer Misperceptions and Equilibrium in Insurance Markets." in Proceedings of Conference on Regulation. International Institute of Management, West Berlin.

Kunreuther, H. 1976. "Limited Knowledge and Insurance Protection," Public Policy, 24:227-261.

Kunreuther, H., R. Ginsberg, L. Miller, P. Sagi, P. Slovic, B. Borkan, and N. Katz. 1978. Disaster Insurance Protection: Public Policy Lessons, 
Wiley Interscience.

Niyasaki, H. 1977. "The rat race and internal labor markets." The Bell Journal of Economics, 8: 394-418.

Pauly, V. i 974 . "Over Insurance and Public Provision of Insurance: The Roles of Moral Hazard and Adverse Selection." Quarterly Journal of Economics, 88:44-62.

Riley, J. 1979. "Informational Equilibrium," Econometrica, 47:331-358.

Rothschild, N., and J. Stiglitz. 1976. "Equilibrium in competitive insurance markets: An essay in the economics of imperfect information." Quarterly Journal of Economics, 90:629-649.

Spence, N. 1973. "Job Narket Signaling," Quarterly Journal of Economics," 87:355-374.

Spence, M. 1978. "Product differentiation and consumer choice in insurance markets." Joumal of Public Economics, 10:427-44.7.

Williamson, O., M. Wachter, and J. Harris. 1975. "Understanding the Employment Relation: The Analysis of Idiosyncratic Exchange." The Bell Joumal of Economics, 6:250-278.

Wilson, C. 1977. "A model of insurance markets with incomplete information." Journal of Economic Theory, 16: 167-207. 